\title{
Kala- ja kasviöljylisäysten vaikutus maidon CLA-pitoisuuteen ja maitoras- van depressioon
}

Kukka Ankeriasniemi $^{1}{ }^{1}$, Piia Kairenius ${ }^{2)}$, Vesa Toivonen ${ }^{2)}$, Seppo Ahvenjärvi ${ }^{2)}$, Aila Vanhatalo ${ }^{1)}$, Pekka Huhtanen ${ }^{2}$ ja Kevin Shingfield ${ }^{2)}$

${ }^{1)}$ MTT, Kotieläintuotannon tutkimus 31600 Jokioinen, nykyinen osoite Helsingin yliopisto, PL 27,
00014 Helsingin yliopisto, etunimi.sukunimi@helsinki.fi
${ }^{2)}$ MTT, Kotieläintuotannon tutkimus 31600 Jokioinen, etunimi.sukunimi@mtt.fi

\section{Tiivistelmä}

Maitorasvan konjugoidun linolihapon (CLA) pitoisuuden nostaminen perustuu ruokintastrategiaan, jolla vakseenihapon virtausta pötsistä pyritään lisäämään. Tällainen ruokinta muuttaa yleensä myös trans-10 ja trans-11 oktadekeenihappojen $\left(\mathrm{C}_{18: 1}\right)$ pitoisuuksia maitorasvassa. Varsinkin trans-10 oktadekeenihapon lisääntynyt pitoisuus maitorasvassa on yhdistetty maidon rasvapitoisuuden pienenemiseen (maitorasvan depressio) sekä CLA:n erityksen pienenemiseen maitorauhasessa. Tämän tutkimuksen tarkoituksena oli vaikuttaa kala- ja kasviöljyjen avulla pötsin biohydrogenaatioon siten, että maitorasvan CLA-pitoisuus nousee, sekä selvittää, mitkä tekijät mahdollisesti aiheuttavat maitorasvan depressiota. Lisäksi tarkoituksena oli tutkia, ovatko kalaöljyn avulla saadut muutokset trans- $\mathrm{C}_{18: 1}$ muodostumisessa yhteydessä ruokinnan monityydyttymättömien rasvahappojen lähteeseen. Tutkimus tehtiin neljällä pötsifistelöidyllä Ay-rotuisella lypsylehmällä, joiden perusrehuina olivat rajoittuneesti käynyt nurmisäilörehu sekä ohrapohjainen väkirehu suhteessa 60:40 (kontrolliruokinta). Koe suoritettiin 4 x 4 latinalaisen neliön koemallin mukaan, ja koekäsittelyinä olivat (1) kontrolli, (2) kalaöljy $200 \mathrm{~g} / \mathrm{pv}$ (K), (3) kalaöljy $200 \mathrm{~g} / \mathrm{pv}$ + auringonkukkaöljy $500 \mathrm{~g} / \mathrm{pv}$ (KA; runsaasti linolihappoa) sekä (4) kalaöljy 200 $\mathrm{g} / \mathrm{pv}+$ pellavaöljy $500 \mathrm{~g} / \mathrm{pv}$ (KP; runsaasti linoleenihappoa).

Öljylisät vaikuttivat eri tavoin maitorasvan CLA-pitoisuuteen. Näistä KP-käsittely nosti cis9,trans-11 CLA:n pitoisuutta KA-käsittelyyn verrattuna (3143 ja $1842 \mathrm{mg} / 100 \mathrm{~g}$ rasvahappoja; RH, vastaavasti). Lisäksi se nosti trans-11 $\mathrm{C}_{18: 1}$ pitoisuutta enemmän kuin kalaöljy-linolihappolisä $(\mathrm{P}<0.01)$ (KP ja KA 7.66 ja $4.68 \mathrm{~g} / 100 \mathrm{~g} \mathrm{RH}$, vastaavasti). Kasviöljylisät nostivat trans-10 $\mathrm{C}_{18: 1}$ pitoisuutta pelkkään kalaöljyyn verrattuna $(\mathrm{P}<0.01)$, ja KA-käsittely nosti sitä enemmän kuin KP-käsittely $(\mathrm{P}=0.07)$ (KA ja KP 9.43 ja $6.85 \mathrm{~g} / 100 \mathrm{~g} \mathrm{RH}$, vastaavasti), samoin kuin trans-10,cis-12 CLA:n pitoisuutta (KA ja KP 21.5 ja $5.78 \mathrm{~g} / 100 \mathrm{~g} \mathrm{RH}$, vastaavasti).

Tämän kokeen perusteella kalaöljy-linoleenihappolisä nostaa maidon CLA-pitoisuutta enemmän kuin kalaöljy-linolihappolisä, kun lehmä on nurmisäilörehupohjaisella ruokinnalla. Vaikka kalaöljylinolihappokäsittely nosti maidon rasvasynteesin estoon liitettyjen trans-10,cis-12 CLA:n ja trans-10 oktadekeenihapon pitoisuuksia, se ei kuitenkaan pienentänyt maidon rasvapitoisuutta kalaöljylinoleenihappokäsittelyyn verrattuna, joten tämän kokeen perusteella pelkästään nämä rasvahapot eivät selitä maitorasvan depressiota. Kalaöljyn lisänä annetut kasviöljyt nostivat trans-oktadekeenihappojen $(\mathrm{P}<0.001)$ ja pienensivät lyhytketjuisten rasvahappojen $(\mathrm{P}<0.001)$ pitoisuutta maidossa pelkkään kalaöljyyn verrattuna, joten on mahdollista, että nämä käsittelyt ovat nostaneet maitorasvan sulamispistettä siinä määrin, että sen eritys maitorauhasessa on hidastunut.

Tutkimus kuuluu MTT:ssä meneillään olevaan EU:n rahoittamaan BioCLA-projektiin (Production of CLA enriched dairy products by natural means).

Asiasanat: Kalaöljy, auringonkukkaöljy, pellavaöljy, lypsylehmä, CLA, trans-oktadekeenihapot, maitorasvan depressio 


\section{Johdanto}

Märehtijän maidon rasvassa on luontaisesti konjugoituneita linolihappoja (CLA). Ne ovat linolihapon $\left(\mathrm{C}_{18: 2} n-6\right)$ paikka- ja geometrisiä isomeerejä, joiden kaksoissidokset ovat konjugoituneet (AbuGhazaleh ym. 2003b). Konjugoituja linolihappoja on tutkittu viime aikoina hyvin intensiivisesti, sillä joillakin CLA:n isomeereillä, varsinkin cis-9,trans-11- ja trans-10,cis-12-CLA:1la, on todettu olevan myönteisiä terveysvaikutuksia. Niiden on todettu $\mathrm{mm}$. hidastavan syöpäkasvaimen kehittymistä, ehkäisevän diabetesta ja parantavan immuunisysteemin toimintaa (Parodi 1997, Ip ym. 1999). Maidon CLApitoisuuden nostaminen ruokinnan avulla onkin tavoitteena monissa tutkimushankkeissa.

Konjugoidun linolihapon esiintyminen märehtijän maidossa riippuu rehun monityydyttymättömien rasvahappojen biohydrogenaatiosta pötsissä. Linoli- ja linoleenihapon $\left(C_{18: 3} n-3\right)$ biohydrogenaatiossa muodostuu cis-9,trans-11-CLA:ta, josta suurin osa biohydrogenoituu edelleen vakseenihapoksi (trans-11 $\left.\mathrm{C}_{18: 1}\right)$ ja steariinihapoksi $\left(\mathrm{C}_{18: 0}\right)$ (Chilliard ym. 2000). Pötsiin saattaa kerääntyä runsaasti vakseenihappoa, jos biohydrogenaatio on epätäydellinen. Maitorauhasessa vakseenihaposta muodostuu $\Delta^{9}$-desaturaasientsyymin vaikutuksesta cis-9, trans-11-CLA:ta, joka on maidon pääasiallisin CLAisomeeri (Griinari ym. 2000). Maidon sisältämien trans-rasvahappojen on todettu lisäävän sydän- ja verisuonisairauksien riskiä (Willett ym. 1993), mutta esimerkiksi vakseenihappo ei välttämättä ole ihmisten terveydelle haitallinen, sillä se voi muuttua CLA:ksi myös ihmisen elimistössä (Salminen ym. 1998). Märehtijän ruokinnan kalaöljylisä estää vakseenihapon biohydrogenoitumista steariinihapoksi, jolloin maidon cis-9,trans-11 CLA:n ja vakseenihapon pitoisuudet nousevat (Whitlock ym. 2002, Ärölä ym. 2002). Ruokinnan linoli- ja linoleenihappolisäysten yhteydessä maidon cis-9,trans-11 CLA:n ja vakseenihapon pitoisuudet nousevat korkeammiksi, jos samanaikaisesti annetaan kalaöljyä (Whitlock ym. 2002, AbuGhazaleh ym. 2004).

Ruokinnan aiheuttama maidon rasvapitoisuuden pieneneminen eli maitorasvan depressio on tila, jossa maidon rasvapitoisuus pienenee ja maidon rasvahappokoostumus muuttuu (Bauman ja Griinari 2003). Maitorasvan depressiota aiheuttavat korkea väkirehutaso sekä dieetin sisältämät monityydyttymättömät rasvahapot (Davis ja Brown 1970), jotka biohydrogenoituvat pötsissä trans-10-reittiä pitkin (Griinari ja Bauman 1999). Tätä reittiä pitkin syntyvien trans-10,cis-12 CLA:n sekä trans-10 oktadekeenihappojen arvellaan myös pienentävän maidon cis-9,trans-11 CLA:n pitoisuutta (Baumgard ym. 2000). AbuGhazalehin ym. (2003a ja 2003b) tutkimuksissa kalaöljyn ja auringonkukansiementen seos on nostanut maidon trans-10 oktadekeenihapon ja trans-10,cis-12 CLA:n pitoisuuksia, mutta kalaöljyn ja pellavaöljyn seos ei vaikuttanut näiden rasvahappojen pitoisuuksiin.

Tämän tutkimuksen tarkoituksena oli vaikuttaa pötsin biohydrogenaatioon siten, että maitorasvan CLA-pitoisuus nousee. Tutkimuksessa testattavat hypoteesit olivat: 1) kalaöljy kombinaationa auringonkukkaöljyn (runsaasti linolihappoa $\mathrm{C}_{18: 2} n-6$ ) tai pellavaöljyn (runsaasti linoleenihappoa $\mathrm{C}_{18: 3}$ n-3) kanssa nostaa maitorasvan CLA-pitoisuutta enemmän kuin pelkkä kalaöljy, ja 2) kalaöljyn ja auringonkukkaöljyn kombinaatio pelkkään kalaöljyyn verrattuna tuottaa enemmän trans-10 oktadekeenihappoa vakseenihapon kustannuksella. Tämän tutkimuksen tarkoituksena oli selvittää, mitkä tekijät mahdollisesti aiheuttavat maitorasvan depressiota, ja ovatko kalaöljyn avulla saadut muutokset

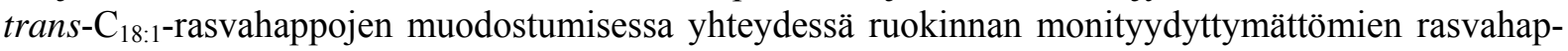
pojen lähteeseen.

\section{Aineisto ja menetelmät}

Koe sisälsi yhteensä neljä 21 päivän pituista koejaksoa, joista kaksi ensimmäistä viikkoa olivat valmistuskautta ja kolmas viikko oli keruukausi. Koe-eläiminä käytettiin neljää pötsifistelöityä Ay-rotuista lypsylehmää, jotka olivat kokeen aikana laktaatiokauden loppuvaiheessa. Lehmien kokonaiskuivaaineen syöntiä rajoitettiin 90 prosenttiin ennen koetta mitatusta keskimääräisestä syönnistä. Karkearehuna oli rajoittuneesti käynyt timotei-nurminatasäilörehu, ja väkirehuseos oli ohrapohjainen. Karkearehun ja väkirehun suhde oli 60:40 (kontrolliruokinta). Öljyjä annettiin lehmille väkirehuannoksiin sekoitettuina. Koe suoritettiin 4 x 4 latinalaisen neliön koemallin mukaan, ja koekäsittelyinä olivat (1) kontrolli, (2) kalaöljy 200 g/pv (K), (3) kalaöljy 200 g/pv + auringonkukkaöljy 500 g/pv (KA) sekä (4) kalaöljy $200 \mathrm{~g} / \mathrm{pv}$ + pellavaöljy $500 \mathrm{~g} / \mathrm{pv}$ (KP). 
Jokaisen viikon neljältä ensimmäiseltä lypsykerralta otettiin näytteet maidon koostumuksen määrittämiseksi ja kahdelta viimeiseltä lypsykerralta maidon rasvahappokoostumuksen määrittämiseksi. Tulokset analysoitiin SAS-ohjelmiston GLM-proseduurin varianssianalyysillä ja ruokintojen väliset erot testattiin ortogonaalisin kontrastein, jolloin kontrolliruokintaa verrattiin öljyihin (1), kalaöljyä verrattiin KA-käsittelyyn + KP-käsittelyyn (2) ja KA-käsittelyä verrattiin KP-käsittelyyn (3). Tilastollisessa mallissa luokittelevana muuttujana oli eläin, jakso sekä ruokinta eli rehuun lisätyt eri öljyt. Tilastollisissa analyyseissä maidon rasvahappokoostumuksesta käytettiin kunkin jakson kolmannen viikon tuloksia, ja muutamien rasvahappojen osalta tarkasteltiin pitoisuuksien muutoksia viikoittain. Koekäsittelyjen vaikutukset joidenkin rasvahappojen pitoisuuksien viikoittaisiin muutoksiin testattiin toistettujen mittausten mallilla käyttäen SAS-ohjelmiston PROC MIXED -proseduuria, jossa luokittelevina muuttujina olivat eläin, jakso, ruokinta ja aika.

\section{Tulokset ja niiden tarkastelu}

Kokeessa käytetyn säilörehun D-arvo oli 68,0 \%. Vastaavanlaisen timotei-nurminatasäilörehun (Shingfield ym. 2003) pääasiallisin pitkäketjuinen rasvahappo oli linoleenihappo (C18:3 n-3) (56 $\mathrm{g} / 100 \mathrm{~g}$ rasvahappoja; RH). Vastaavanlaisen väkirehun (Shingfield ym. 2003) merkittävimmät rasvahapot olivat linolihappo (C18:2 n-6) (33,5 g/100 g RH), öljyhappo (C18:1 cis-9) (29,6 g/100 g RH) sekä palmitiinihappo (C16:0) (20,7 g/100 g RH). Kalaöljyssä (Shingfield ym. 2003) oli runsaasti yli 20 hiiltä sisältäviä pitkäketjuisia monityydyttymättömiä rasvahappoja, erityisesti eikosapentaeenihappoa (EPA C20:5 n-3) ja dokoheksaeenihappoa (DHA C22:6 n-3) (20,2 ja 12,9 g/100 g RH, vastaavasti). Auringonkukkaöljyssä (Shingfield ym. 2005) oli eniten linolihappoa (64,9 g/100 g RH) ja pellavaöljyssä runsaasti erityisesti linoleenihappoa (60,8 g/100 g RH).

Öljylisät ruokinnassa pienensivät EKM-tuotosta sekä maidon rasvapitoisuutta ja -tuotosta kontrolliin verrattuna $(\mathrm{P}=0,06)$ (taulukko 1). Pelkkään kalaöljyyn verrattuna kasviöljylisät pienensivät edelleen maito-, laktoosi- ja rasvatuotoksia sekä maidon laktoosipitoisuutta, mutta nostivat maidon valkuaispitoisuutta $(\mathrm{P}=0,10)$. Pelkkä kalaöljy on aikaisemmissa tutkimuksissa pienentänyt maitotuotosta (Shingfield ym. 2003), mutta ei vastaavalla annostustasolla maidon rasvapitoisuutta (Kairenius 2003, Shingfield ym. 2003). Linoli- tai linoleenihappolisät yhdessä kalaöljyn kanssa eivät ole aikaisemmin vaikuttaneet maitotuotokseen, mutta linolihappo yhdessä kalaöljyn kanssa on pienentänyt maidon rasvapitoisuutta (AbuGhazaleh ym. 2003a). Öljylisät pienensivät de novo -synteesistä peräisin olevien $\mathrm{C}_{4: 0}-\mathrm{C}_{14: 0}$ rasvahappojen pitoisuutta maitorasvassa kontrolliin verrattuna (taulukko 2), ja kasviöljylisät pienensivät näiden rasvahappojen sekä palmitiinihapon pitoisuutta pelkkään kalaöljyyn verrattuna. Tulokset ovat yhdenmukaisia Whitlockin ym. (2002) tutkimuksen kanssa, jossa lypsylehmien ruokintaan lisättiin kalaöljyä ja ekstrudoituja soijapapuja (runsaasti linolihappoa).

Taulukko 1. Öljylisien vaikutus maitotuotokseen ja maidon koostumukseen.

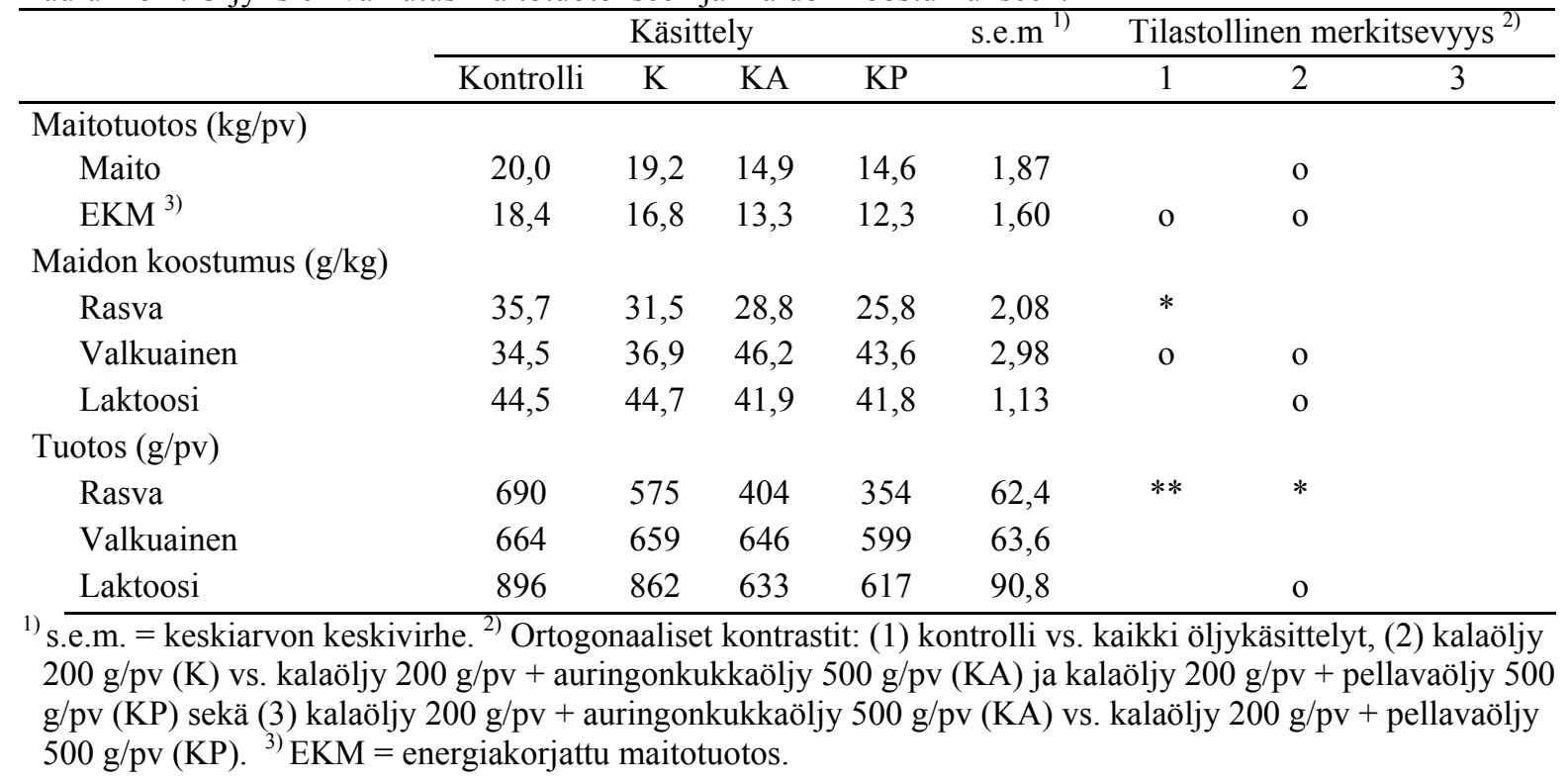


Taulukko 2. Öljylisien vaikutus maidon rasvahappokoostumukseen (g/100 g rasvahappoja).

\begin{tabular}{|c|c|c|c|c|c|c|c|c|}
\hline & \multicolumn{4}{|c|}{ Käsittely } & \multirow[t]{2}{*}{ s.e.m ${ }^{1)}$} & \multicolumn{3}{|c|}{ Tilastollinen merkitsevyys $^{2)}$} \\
\hline & Kontrolli & $\mathrm{K}$ & KA & $\mathrm{KP}$ & & 1 & 2 & 3 \\
\hline $\mathrm{C}_{4: 0}$ & 4,41 & 4,37 & 2,01 & 1,93 & 0,191 & $* * *$ & $* * *$ & \\
\hline $\mathrm{C}_{6: 0}$ & 2,89 & 2,09 & 0,87 & 0,82 & 0,087 & $* * *$ & $* * *$ & \\
\hline $\mathrm{C}_{8: 0}$ & 1,30 & 1,18 & 0,42 & 0,40 & 0,079 & $* * *$ & $* * *$ & \\
\hline $\mathrm{C}_{10: 0}$ & 2,98 & 2,69 & 0,96 & 0,94 & 0,242 & $* *$ & $* * *$ & \\
\hline $\mathrm{C}_{12: 0}$ & 3,46 & 3,23 & 1,50 & 1,47 & 0,294 & $* *$ & $* *$ & \\
\hline $\mathrm{C}_{14: 0}$ & 11,2 & 10,9 & 7,30 & 7,15 & 0,425 & $* * *$ & $* * *$ & \\
\hline $\mathrm{C}_{16: 0}$ & 25,4 & 23,8 & 21,1 & 20,4 & 0,794 & $* *$ & $*$ & \\
\hline $\mathrm{C}_{16: 1}$ & 0,72 & 0,88 & 0,98 & 1,06 & 0,161 & & & \\
\hline $\mathrm{C}_{18: 0}$ & 10,4 & 6,16 & 7,91 & 4,98 & 0,510 & $* * *$ & & $* *$ \\
\hline $\mathrm{C}_{18: 1}$ cis yht. & 16,9 & 12,5 & 16,3 & 12,6 & 0,685 & $* *$ & $\mathrm{o}$ & $* *$ \\
\hline $\mathrm{C}_{18: 1}$ trans yht. & 3,73 & 9,82 & 20,0 & 21,2 & 1,094 & $* * *$ & $* * *$ & \\
\hline $\mathrm{C}_{18: 1}$ yht. & 20,6 & 22,4 & 36,3 & 33,8 & 1,253 & $* * *$ & $* * *$ & \\
\hline $\mathrm{C}_{18: 2}(n-6)^{3)}$ & 1,51 & 1,35 & 1,54 & 1,44 & 0,146 & & & \\
\hline CLA yht. ${ }^{4)}$ & 0,78 & 2,27 & 2,24 & 3,56 & 0,289 & $* * *$ & & $*$ \\
\hline $\mathrm{C}_{18: 3}(n-3)^{5)}$ & 0,61 & 0,52 & 0,39 & 0,53 & 0,016 & $* * *$ & $*$ & $* * *$ \\
\hline$C_{20: 5}(n-3)$ EPA & 0,09 & 0,15 & 0,07 & 0,07 & 0,012 & & $* *$ & \\
\hline C22:6(n-3) DHA & 0,04 & 0,09 & 0,03 & 0,03 & 0,009 & & $* *$ & \\
\hline Tyydyttyneet yht. & 65,6 & 59,2 & 46,2 & 42,3 & 1,648 & $* * *$ & $* * *$ & \\
\hline Monoeenit yht. & 24,6 & 28,4 & 42,6 & 40,5 & 1,326 & $* * *$ & $* * *$ & \\
\hline Polyeenit yht. & 9,79 & 12,4 & 11,2 & 17,2 & 0,567 & $* * *$ & $*$ & $* * *$ \\
\hline
\end{tabular}

$1)$ s.e.m. = keskiarvon keskivirhe. ${ }^{2)}$ Ortogonaaliset kontrastit: (1) kontrolli vs. kaikki öljykäsittelyt, (2) kalaöljy 200 g/pv (K) vs. kalaöljy 200 g/pv + auringonkukkaöljy 500 g/pv (KA) ja kalaöljy 200 g/pv + pellavaöljy 500 g/pv (KP) sekä (3) kalaöljy 200 g/pv + auringonkukkaöljy 500 g/pv (KA) vs. kalaöljy 200 g/pv + pellavaöljy 500 $\mathrm{g} / \mathrm{pv}(\mathrm{KP}) .{ }^{3)}$ Linolihappo. ${ }^{4)}$ Konjugoitu linolihappo, kaikki isomeerit. ${ }^{5)} \alpha$-linoleenihappo.

Öljylisät ruokinnassa pienensivät öljyhapon $\left(\mathrm{C}_{18: 1}\right.$ cis-9) pitoisuutta $(\mathrm{P}<0,01)$ sekä nostivat vakseenihapon ja trans-10 oktadekeenihapon pitoisuuksia maitorasvassa kontrolliin verrattuna $(\mathrm{P}<0,01)$ (taulukko 3), samoin kuin Shingfieldin ym. (2003) tutkimuksessa. Tässä tutkimuksessa pelkkään kalaöljyyn verrattuna kasviöljyt nostivat vakseenihapon sekä trans-10 oktadekeenihapon pitoisuuksia $(\mathrm{P}<0,05)$. Myös Whitlock’n ym. (2002) tutkimuksessa kalaöljy-linolihappolisä nosti vakseenihapon pitoisuutta kontrolliin (ei öljylisää) verrattuna. Offerin ym. (2001) tutkimuksessa pelkkä linolihappolisä ei nostanut maidon trans-10 oktadekeenihapon pitoisuutta. Tässä tutkimuksessa KA-käsittely nosti trans-10 oktadekeenihapon pitoisuutta enemmän kuin KP-käsittely ( $\mathrm{P}=0,07)$, kun taas KP-käsittely nosti vakseenihapon pitoisuutta enemmän kuin KA-käsittely $(\mathrm{P}<0,01)$.

Öljylisät ruokinnassa nostivat kokonais-CLA:n sekä useimpien CLA-isomeerien pitoisuuksia kontrolliin verrattuna $(\mathrm{P}=0,07)$ (taulukko 4). Pelkkään kalaöljyyn verrattuna kasviöljyt nostivat $\mathrm{mm}$. trans-7,cis-9 CLA:n sekä trans-10,cis-12 CLA:n pitoisuuksia ( $<<0,01)$. Samansuuntainen vaikutus on aikaisemmin saatu aikaan maitorasvan depressiota aiheuttavalla ruokinnalla (25\% karkearehua, $70 \%$ väkirehua ja $5 \%$ soijaöljyä) (Piperova ym. 2000). Kalaöljy-auringonkukkaöljykäsittely nosti trans10,cis-12 CLA:n pitoisuutta selvästi enemmän kuin KP-käsittely $(\mathrm{P}<0,01)$, samoin kuin AbuGhazalehin ym. (2003a) tutkimuksessa, jossa kalaöljy-linolihappolisä myös pienensi maidon rasvapitoisuutta. Trans-10 oktadekeenihapon sekä trans-10,cis-12 CLA:n on aiemminkin arveltu pienentävän maidon rasvapitoisuutta (Baumgard ym. 2000). Tässä tutkimuksessa KA-käsittely nosti näiden molempien rasvahappojen pitoisuutta, mutta se ei kuitenkaan vaikuttanut maidon rasvapitoisuuden pienenemiseen.

Pelkkään kalaöljyyn verrattuna KP-käsittely nosti kokonais-CLA:n sekä cis-9,trans-11 CLA:n pitoisuuksia, kun taas KA-käsittely ei enää nostanut niiden pitoisuuksia. Vaikutus oli samansuuntainen Ramaswamyn ym. (2001) ja Whitlockin ym. (2002) tutkimusten kanssa. Tässä tutkimuksessa kalaöljypellavaöljykäsittely nosti sekä kokonais-CLA:n että cis-9,trans-11 CLA:n pitoisuuksia KA-käsittelyyn verrattuna $(\mathrm{P}<0,05)$. Linoli- ja linoleenihappojen vaikutuksista kalaöljyn kanssa maidon CLApitoisuuteen on tehty vasta muutama tutkimus, ja ne ovat viitanneet siihen, että päinvastoin kuin tässä 
Taulukko 3. Öljylisien vaikutus maidon $\mathrm{C}_{18: 1}$-rasvahappokoostumukseen (g/100 g rasvahappoja).

\begin{tabular}{|c|c|c|c|c|c|c|c|c|}
\hline & \multicolumn{4}{|c|}{ Käsittely } & \multirow[t]{2}{*}{ s.e.m ${ }^{1)}$} & \multicolumn{3}{|c|}{ Tilastollinen merkitsevyys ${ }^{2)}$} \\
\hline & Kontrolli & $\mathrm{K}$ & KA & $\mathrm{KP}$ & & 1 & 2 & 3 \\
\hline trans-4 & 0,03 & 0,04 & 0,05 & 0,04 & 0,005 & & & \\
\hline trans-5 & 0,03 & 0,03 & 0,05 & 0,04 & 0,005 & & & o \\
\hline trans $-6+7+8$ & 0,21 & 0,49 & 0,98 & 0,88 & 0,049 & $* * *$ & $* * *$ & \\
\hline trans-9 & 0,24 & 0,58 & 0,88 & 0,99 & 0,045 & $* * *$ & $* * *$ & \\
\hline trans-10 & 0,26 & 0,80 & 9,43 & 6,85 & 0,838 & $* * *$ & $* * *$ & o \\
\hline trans-11 ${ }^{3)}$ & 1,41 & 4,19 & 4,68 & 7,66 & 0,500 & $* * *$ & * & $* *$ \\
\hline trans-12 & 0,23 & 1,00 & 1,19 & 1,25 & 0,068 & $* * *$ & $*$ & \\
\hline trans $-13+14$ & 0,47 & 1,40 & 1,60 & 2,03 & 0,092 & $* * *$ & $* *$ & $*$ \\
\hline trans-15 & 0,57 & 0,76 & 0,77 & 0,92 & 0,044 & $* *$ & & o \\
\hline trans-16+cis-14 & 0,29 & 0,54 & 0,40 & 0,53 & 0,034 & $* *$ & & $*$ \\
\hline cis-9 ${ }^{4)}$ & 16,0 & 11,2 & 14,2 & 10,1 & 0,663 & $* *$ & & $* *$ \\
\hline cis-11 & 0,48 & 0,66 & 1,03 & 1,10 & 0,081 & $* *$ & $* *$ & \\
\hline cis-12 & 0,14 & 0,16 & 0,32 & 0,16 & 0,018 & $* *$ & $*$ & $* * *$ \\
\hline cis-13 & 0,06 & 0,13 & 0,21 & 0,20 & 0,010 & $* * *$ & $* * *$ & \\
\hline cis- 15 & 0,10 & 0,27 & 0,36 & 0,83 & 0,041 & $* * *$ & $* * *$ & $* * *$ \\
\hline cis-16 & 0,08 & 0,16 & 0,17 & 0,23 & 0,009 & $* * *$ & $*$ & $* *$ \\
\hline
\end{tabular}

${ }^{1)}$ s.e.m. = keskiarvon keskivirhe. ${ }^{2)}$ Ortogonaaliset kontrastit: (1) kontrolli vs. kaikki öljykäsittelyt, (2) kalaöljy 200 g/pv (K) vs. kalaöljy 200 g/pv + auringonkukkaöljy 500 g/pv (KA) ja kalaöljy 200 g/pv + pellavaöljy 500 g/pv (KP) sekä (3) kalaöljy 200 g/pv + auringonkukkaöljy 500 g/pv (KA) vs. kalaöljy 200 g/pv + pellavaöljy $500 \mathrm{~g} / \mathrm{pv}(\mathrm{KP}){ }^{3)}$ vakseenihappo. ${ }^{4)}$ öljyhappo.

Taulukko 4. Öljylisien vaikutus maidon CLA-koostumukseen (mg/100 g rasvahappoja).

\begin{tabular}{|c|c|c|c|c|c|c|c|c|}
\hline & \multicolumn{4}{|c|}{ Käsittely } & \multirow[t]{2}{*}{ s.e.m ${ }^{1)}$} & \multicolumn{3}{|c|}{ Tilastollinen merkitsevyys ${ }^{2)}$} \\
\hline & Kontrolli & $\mathrm{K}$ & KA & $\mathrm{KP}$ & & 1 & 2 & 3 \\
\hline trans-6,trans-8 & 3,71 & 8,54 & 6,63 & 6,30 & 0,47 & $* * *$ & $* *$ & \\
\hline trans-7,cis-9 & 32,5 & 115 & 167 & 164 & 8,79 & $* * *$ & $* *$ & \\
\hline trans-7,trans-9 & 9,12 & 13,2 & 9,91 & 9,46 & 0,81 & & $* *$ & \\
\hline trans-8,cis-10 & 7,59 & 19,8 & 29,4 & 44,4 & 6,00 & $* *$ & o & \\
\hline trans- 8, trans -10 & 1,73 & 5,03 & 10,2 & 8,44 & 0,756 & $* * *$ & $* *$ & \\
\hline trans-9,cis-11 & 6,45 & 14,5 & 97,0 & 88,5 & 7,34 & $* * *$ & $* * *$ & \\
\hline trans-9,trans-11 & 15,0 & 18,5 & 14,5 & 16,2 & 1,49 & & & \\
\hline trans-10,cis-12 & 1,39 & 1,25 & 21,5 & 5,78 & 2,32 & $*$ & $* *$ & $* *$ \\
\hline trans-10,trans- 12 & 2,01 & 2,64 & 7,16 & 6,31 & 0,52 & $* * *$ & $* * *$ & \\
\hline trans-11,cis-13 & 41,7 & 34,7 & 13,1 & 35,8 & 6,63 & & & $*$ \\
\hline trans- 11 ,trans- 13 & 9,94 & 5,19 & 3,46 & 8,00 & 0,65 & $* * *$ & & $* *$ \\
\hline trans-12,cis-14 & 3,59 & 9,69 & 4,63 & 5,59 & 1,19 & o & $*$ & \\
\hline trans-12,trans-14 & 7,34 & 9,09 & 6,99 & 11,7 & 0,63 & $*$ & & $* *$ \\
\hline trans-13,trans- 15 & 1,02 & 2,11 & 0,15 & 1,82 & 0,27 & & $*$ & $* *$ \\
\hline cis-8,trans-10 & 3,80 & 4,39 & 0,00 & 0,00 & 2,38 & & & \\
\hline cis-9,trans-11 & 630 & 1998 & 1842 & 3143 & 270 & $* *$ & & $* *$ \\
\hline cis-11,trans-13 & 0,58 & 3,63 & 1,85 & 3,21 & 0,38 & $* *$ & o & $*$ \\
\hline cis-12,trans-14 & 1,26 & 0,95 & 0,51 & 1,19 & 0,41 & & & \\
\hline trans,trans CLA & 49,9 & 64,3 & 59,1 & 68,1 & 3,22 & $* *$ & & o \\
\hline cis,trans/trans,cis CLA & 777 & 2264 & 2235 & 3558 & 288 & $* * *$ & & $*$ \\
\hline
\end{tabular}

${ }^{1)}$ s.e.m. = keskiarvon keskivirhe. ${ }^{2)}$ Ortogonaaliset kontrastit: (1) kontrolli vs. kaikki öljykäsittelyt, (2) kalaöljy 200 g/pv (K) vs. kalaöljy 200 g/pv + auringonkukkaöljy 500 g/pv (KA) ja kalaöljy 200 g/pv + pellavaöljy 500 g/pv (KP) sekä (3) kalaöljy 200 g/pv + auringonkukkaöljy 500 g/pv (KA) vs. kalaöljy 200 g/pv + pellavaöljy $500 \mathrm{~g} / \mathrm{pv}(\mathrm{KP})$. 
tutkimuksessa, kalaöljy-linolihappolisä nostaa CLA-pitoisuutta enemmän kuin kalaöljy-linoleenihappolisä (AbuGhazaleh ym. 2003a ja 2003b). Niissä tutkimuksissa lehmät saivat väkirehua ja karkearehua suhteessa 50:50 ja karkearehuna oli maissi- ja sinimailassäilörehu.

Muutamien rasvahappojen osalta tarkasteltiin pitoisuuksien muutoksia viikoittain (kuva 1). Taustalla oli ajatus siitä, että koejakson pituus saattaisi mahdollisesti vaikuttaa rasvahappojen pitoisuuksien muutoksiin. Pelkkään kalaöljyyn verrattuna KA- ja KP-käsittelyt nostivat jo toisella koeviikolla trans-10 oktadekeenihapon pitoisuutta $(\mathrm{P}<0,01)$, ja kolmannella viikolla pitoisuudet eivät enää muuttuneet merkitsevästi. Koejakson pituus näytti olevan riittävä KA- ja KP-käsittelyiden vaikutusten aikaansaamiseksi, mutta niiden väliset erot olisivat ehkä tulleet paremmin näkyville, jos koejakson pituus olisi ollut pidempi. Kontrolli- ja kalaöljykäsittelyillä pitoisuudet pienenivät, mikä johtunee aiempien käsittelyjen jälkivaikutuksesta. Näiden koekäsittelyjen kannalta olisi ollut parempi käyttää pidempää koejaksoa.
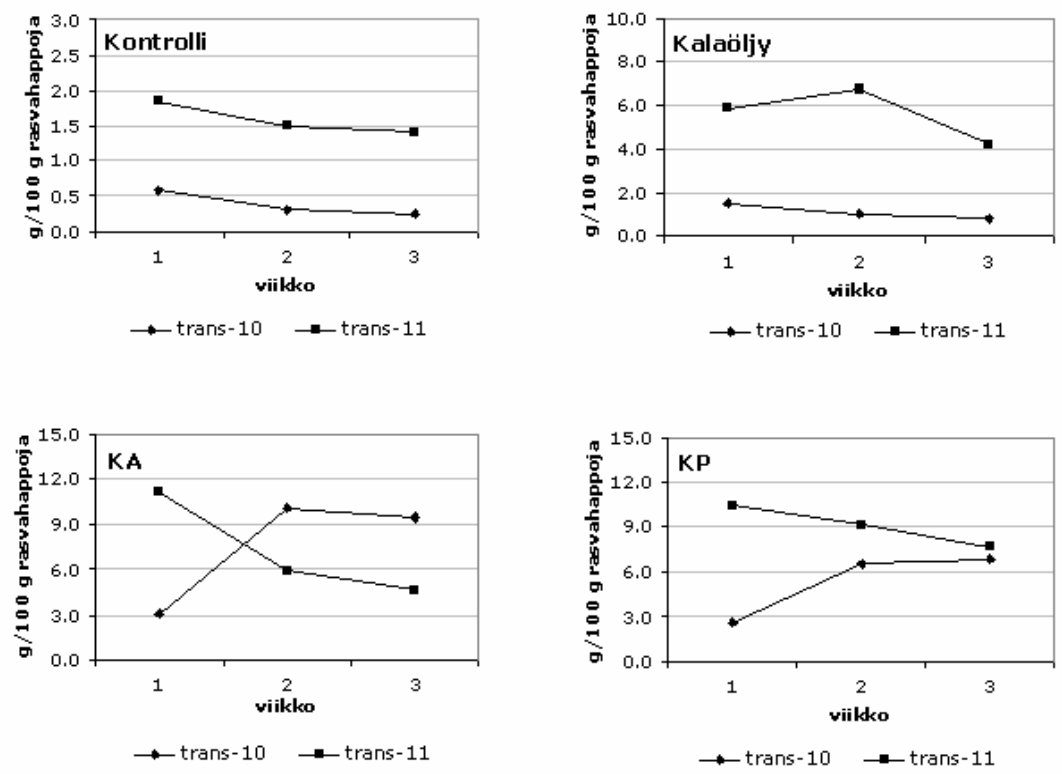

Kuva 1. Koeviikon vaikutus trans-10 oktadekeenihapon ( $\diamond$, s.e.m. 1,21$)$ ja vakseenihapon (trans-11) ( $\mathbf{\square}$, s.e.m. 1,01) pitoisuuksiin.

\section{Johtopäätökset}

Kasviöljylisät vaikuttivat eri tavoin maidon CLA-pitoisuuteen. Pelkkään kalaöljyyn verrattuna KPkäsittely nosti kokonais-CLA:n sekä cis-9,trans-11 CLA:n pitoisuuksia, kun taas KA-käsittely ei muuttanut niitä. Tämän kokeen perusteella kalaöljy-linoleenihappolisä nostaa maidon CLA-pitoisuutta enemmän kuin kalaöljy-linolihappolisä, kun lehmä on nurmisäilörehupohjaisella ruokinnalla. Auringonkukkaöljy kalaöljyn lisänä tuotti trans-10 oktadekeenihappoa vakseenihapon kustannuksella. Biohydrogenaatioreitin siirtyminen trans-10 oktadekeenihappoa tuottavalle reitille ei ole suotavaa, sillä vakseenihapon vähentyvä tuotanto pienentää maidon cis-9,trans-11 CLA:n ja sitä kautta kokonaisCLA:n pitoisuutta maidossa. Vaikka kalaöljy-linolihappo-käsittely nosti maidon rasvasynteesin estoon liitettyjen trans-10,cis-12 CLA:n ja trans-10 oktadekeenihapon pitoisuuksia, se ei kuitenkaan pienentänyt maidon rasvapitoisuutta kalaöljy-pellavaöljykäsittelyyn verrattuna. Kalaöljyn lisänä annetut kasviöljyt nostivat trans-oktadekeenihappojen ja pienensivät lyhytketjuisten rasvahappojen pitoisuutta maitorasvassa pelkkään kalaöljyyn verrattuna, joten on mahdollista, että nämä rasvahapot ovat nostaneet maitorasvan sulamispistettä niin paljon, että sen eritys maitorauhasessa on hidastunut. Tämän asian selvittämiseksi on kuitenkin syytä tehdä jatkotutkimuksia.

Koejakson pituus ei luultavasti ollut tarpeeksi pitkä kalaöljyn ja kasviöljyjen avulla saatavien vaikutusten aikaansaamiseksi. Kalaöljy-linolihappokäsittelyllä trans-10 oktadekeenihapon pitoisuus olisi saattanut pienentyä ja vakseenihapon pitoisuus puolestaan nousta, jos koejakson pituutta olisi 
jatkettu. Kalaöljy-linoleenihappolisä saattaa hidastaa tai estää biohydrogenaatioreitin siirtymistä trans10 oktadekeenihappoa tuottavalle reitille, mutta tämäkin olisi voitu mahdollisesti selvittää pidemmän koejakson avulla.

\section{Kirjallisuus}

AbuGhazaleh, A.A., Schingoethe, D.J., Hippen, A.R. \& Kalscheur, K.F. 2003a. Conjugated linoleic acid and vaccenic acid in rumen, plasma, and milk of cows fed fish oil and fats differing in saturation of 18 carbon fatty acids. J. Dairy Sci. 86: 3648-3660.

AbuGhazaleh, A.A., Schingoethe, D.J., Hippen, A.R. \& Kalscheur, K.F. 2003b. Milk conjugated linoleic acid response to fish oil supplementation of diets differing in fatty acid profiles. J. Dairy Sci. 86: 944-953.

AbuGhazaleh, A.A., Schingoethe, D.J., Hippen, A.R. \& Kalscheur, K.F. 2004. Conjugated linoleic acid increases in milk when cows fed fish meal and extruded soybeans for an extended period of time. J. Dairy Sci. 87: 1758-1766.

Bauman, D.E. \& Griinari, J.M. 2003. Nutritional regulation of milk fat synthesis. Ann. Rev. Nutr. 23: 203227.

Baumgard, L.H., Corl, B.A., Dwyer, D.A., Sæbø, A. \& Bauman, D.E. 2000. Identification of the conjugated linoleic acid isomer that inhibits milk fat synthesis. Am. J. Phys. 278: R179-R184.

Chilliard, Y., Ferlay, A., Mansbridge, R. \& Doreau, M. 2000. Ruminant milk fat plasticity: nutritional control of saturated, polyunsaturated, trans and conjugated fatty acids. Ann. Zootech. 49: 181-205.

Davis, C.L. \& Brown, R.E. 1970. Low-fat milk syndrome. In: Physiology of digestion and metabolism in the ruminant. Ed. by A.T. Phillipson. pp. 545-565. Newcastle upon Tyne, Oriel, UK.

Griinari, J.M. \& Bauman, D.E. 1999. Biosynthesis of conjugated linoleic acid and its incorporation into meat and milk in ruminants. In: Advances in Conjugated Linoleic Acid Research. Ed. by M.P. Yurawecz, M.M. Mossoba, J.K.G. Kramer, M.W. Pariza \& G.J. Nelson. pp. 180-200. AOCS Press, Champaign, Illinois.

Griinari, J.M., Corl, B.A., Lacy, S.H., Chouinard, P.Y., Nurmela, K.V.V. \& Bauman, D.E. 2000. Conjugated linoleic acid is synthesized endogenously in lactating dairy cows by delta-9-desaturase. J. Nutr. 130: 2285-2291.

Ip, M.M., Masso-Welch, P.A., Shoemaker, S.F., Shea-Eaton, W.K. \& Ip, C. 1999. Conjugated linoleic acid inhibits proliferation and induces apoptosis of normal rat mammary epithelial cells in primary culture. Exp. Cell Res. 250: 22-34.

Kairenius, P. 2003. Kaläljyn vaikutus pötsifermentaatioon ja monityydyttymättömien rasvahappojen biohydrogenaatioon pötsissä säilörehupohjaisella ruokinnalla. Pro Gradu -tutkielma, Helsingin yliopisto.

Offer, N.W., Marsden, M. \& Phipps, R.H. 2001. Effect of oil supplementation of a diet containing a high concentration of starch on levels of trans fatty acids and conjugated linoleic acids in bovine milk. Anim. Sci. 73: 533-540.

Parodi, P.W. 1997. Cows' milk fat components as potential anticarcinogenic agents. J. Nutr. 127: 1055-1060.

Piperova, L.S., Teter, B.B., Bruckental, I., Sampugna, J., Mills, S.E., Yurawecz, M.P., Fritsche, J., Ku, K. \& Erdman, R.A. 2000. Mammary lipogenic enzyme activity, trans fatty acids and conjugated linoleic acids are altered in lactating dairy cows fed a milk fat depressing diet. J. Nutr. 130: 2568-2574.

Ramaswamy, N., Baer, R.J., Schingoethe, D.J., Hippen, A.R., Kasperson, K.M. \& Whitlock, L.A. 2001. Composition and flavor of milk and butter from cows fed fish oil, extruded soybeans, or their combination. J. Dairy Sci. 84: 2144-2151.

Salminen, I., Mutanen, M., Jauhiainen, M. \& Aro, A. 1998. Dietary trans fatty acids increase conjugated linoleic acid levels in human serum. J. Nutr. Biochem. 9: 93-98.

Shingfield, K.J., Ahvenjärvi, S., Toivonen, V., Ärölä, A., Nurmela, K.V.V., Huhtanen, P. \& Griinari, J.M. 2003. Effect of dietary fish oil on biohydrogenation of fatty acids and milk fatty acid content in dairy cows. Anim. Sci. 77: 165-179.

Shingfield, K.J., Reynolds, C.K., Lupoli, B., Toivonen, V., Yurawecz, M.P., Delmonte, P., Griinari, J.M., Grandison, A.S. \& Beever, D.E. 2005. Effect of forage type and proportion of concentrate in the diet on milk fatty acid composition in cows given sunflower oil and fish oil. Anim. Sci. 80: 225-238.

Whitlock, L.A., Schingoethe, D.J., Hippen, A.R., Kalscheur, K.F., Baer, R.J., Ramaswamy, N. \& Kasperson, K.M. 2002. Fish oil and extruded soybeans fed in combination increase conjugated linoleic acids in milk of dairy cows more than when fed separately. J. Dairy Sci. 85: 234-243.

Willett, W.C., Stampfer, M.J., Manson, J.E., Colditz, G.A., Speizer, F.E., Rosner, B.A., Sampson, L.A. \& Hennekens, C.H. 1993. Intake of trans fatty acids and risk of coronary heart disease among women. Lancet 341: 581-585.

Ärölä, A., Shingfield, K.J., Vanhatalo, A., Toivonen, V., Huhtanen, P. \& Griinari, J.M. 2002. Biohydrogenation shift and milk fat depression in lactating dairy cows fed increasing levels of fish oil. In: 2002 Joint meeting, abstracts July 21-25, 2002 Québec City, Canada. J. Dairy Sci. 85, Suppl. 1: 143. 